\title{
ANALYSIS ON THE IMPACT OF COVID-19 ON THE FUTURE OF THE OIL INDUSTRY AT GLOBAL, REGIONAL AND LOCAL LEVEL
}

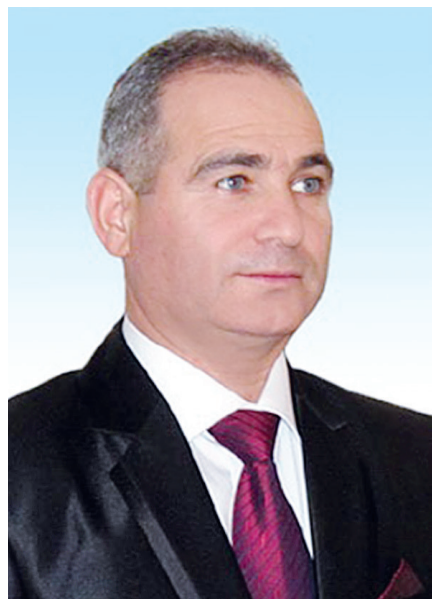

V.P. TUDORACHE ${ }^{*}$, Associate Professor PhD.

Eng. at Petroleum-Gas University of Ploiesti, Vice-President of A.G.I.R. Prahova branch.

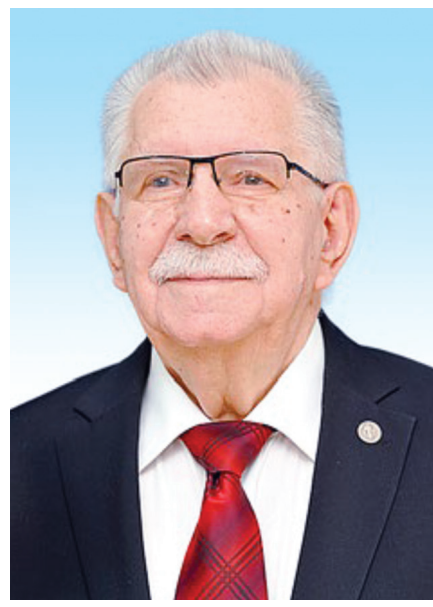

N. ILIAS ${ }^{2}$,

Professor PhD. Eng. at University of Petrosani, Member of the Academy for Technical Sciences of Romania,President of the Section Oil, Mine and Geonomy Engineering

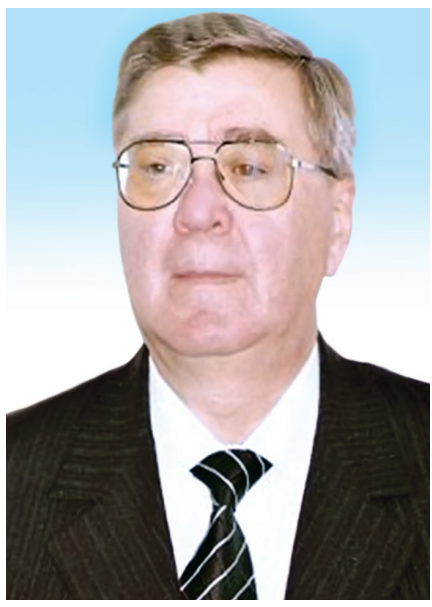

D. FODOR ${ }^{2}$,

Professor PhD. Eng. at University of Petrosani, Universitatii, no. 20, code 3332006, Petrosani, Hunedoara, Romania, and Member of the Academy for Technical Sciences of Romania, Member of the International Mining Committee

1PETROLEUM-GAS UNIVERSITY OF PLOIESTI,

Boulevard Bucharest, no. 39, code 100680, Ploiesti, Prahova, Romania

2UNIVERSITY OF PETROSANI,

Universitatii, no. 20, code 3332006, Petrosani, Hunedoara, Romania

Falling oil prices raise questions about the future of the energy industry globally, regionally and locally, as well as the role of fossil fuels in the transition to a more sustainable energy future after the pandemic. The global economy is already undergoing an energy transition from fossil fuels to more sustainable energy sources. Renewable energy is increasingly deflationary, and oil prices will have to compete with it, despite falling oil prices driven by the economy and pandemic. It is not known what life will look like in the post-"COVID-19» oil industry, even if oil demand returns to normal, supply consumption will take some time. We may see further diversification in the energy market and for renewable energy to play a greater role. However, it is important that energy resources are balanced in a sustainable and equitable way that supports the growth of the

\footnotetext{
${ }^{1 *}$ Author for correspondence. E-mail: valentin.tudorache@yahoo.com
} 
world economy. The objective of the United Nations Sustainable Development to ensure access to "affordable, reliable, sustainable and modern energy for all" will be largely based on policy makers, company strategies and prices.

KEY WORDS: "COVID-19», impact, company, oil, gas, future of the petroleum industry, strategies, price.

\section{МҰНАЙ ӨНЕРКӘСІБІНІҢ БОЛАШАҒЫНА ДҮНИЕЖҮЗІЛІК, ӨңІРЛІК ЖӘНЕ ЖЕРГІЛІКТІ ДЕҢГЕЙЛЕРДЕ «COVID-19» ӘСЕРIН ТАЛДАУ}

Мұнай бағасының құлдырауы жаһандық, өңірлік және жергілікті энергетика саласының болашағы, сондай-ақ пандемиядан кейінгі неғұрлым тұрақты энергетикалық болашаққа көшудегі қазба отынның рөлі туралы мәселелерді көтереді. Қазірдің өзінде жаһандық экономика қазба отынынан неғұрлым тұрақты энергия көздеріне көшуде. Жаңартылатын энергия көздері дефляциялық болып келеді, ал мұнай бағасы экономика мен пандемияға алып келетін мұнай бағасының құлдырауына қарамастан, онымен бәсекелесуге тура келеді. «COVID-19» мұнай өнеркәсібінде өмірдің қандай болатыны белгісіз, тіпті мұнайға деген сұраныс қалыптыға қайтарылса да, ұсынысты тұтыну біраз уақытты алады. Біз энергетикалық нарықта одан әрі әртараптандыруды және жаңартылатын энергия көздерін дамытуда үлкен рөл атқаруын көруіміз мүмкін. Алайда, энергетикалық ресурстардың әлемдік экономиканың өсуін қолдайтын тұрақты және тең құқықты тәсілмен теңгерілгені маңызды. Біріккен Ұлттар Ұйымының "баршаға арналған қол жетімді, сенімді, тұрақты және қазіргі заманғы энергияға" қол жеткізуін қамтамасыз ету жөніндегі міндеті саясаткерлердің, компанияның стратегиялары мен бағаларының негізінде жүзеге асырылады.

TYЙІн CөзДEP: «COVID-19», әсер, компания, мұнай, газ, мұнай-газ саласының болашағы, стратегиясы, бағасы.

\section{АНАЛИЗ ВЛИЯНИЯ «COVID-19» НА БУДУЩЕЕ НЕФТЯНОЙ ПРОМЫШЛЕННОСТИ НА ГЛОБАЛЬНОМ, РЕГИОНАЛЬНОМ И МЕСТНОМ УРОВНЯХ}

Падение цен на нефть поднимает вопросы о будущем энергетической отрасли во всем мире, на региональном и местном уровнях, а также о роли ископаемого топлива в переходе к более устойчивому энергетическому будущему после пандемии. Мировая экономика уже переживает энергетический переход от ископаемого топлива к более устойчивым источникам энергии. Возобновляемые источники энергии становятся все более дефрляионными, и цены на нефть должны будут конкурировать с ней, несмотря на падение цен на нефть, обусловленное экономикой и пандемией. Неизвестно, как будет выглядеть жизнь в нефтяной отрасли после «COVID-19», даже если спрос на нефть вернется в нормальное русло, потребление предложения займет некоторое время. Мы можем увидеть дальнейшую диверсификацию на энергетическом рынке для того, чтобы возобновляемые источники энергии играли более активную роль. Однако важно, чтобы энергетические ресурсы были сбалансированы устойчивым и справедливым образом, который бы поддерживал рост мировой экономики. Цель Организации Объединенных Наций по устойчивому развитию - обеспечить доступ к «доступной, надежной, устойчивой и современной энергии для всех» - будет в значительной степени основываться на директивных организациях, стратегиях и ценах компаний.

КЛЮчЕВЫЕ СЛОВА: «COVID-19», влияние, компания, нефть, газ, будущее нефттяной промышленности, стратегия, цена. 


\section{COVID-19 И НЕФТЯНАЯ ПРОМЫШЛЕННОСТЬ}

\section{INTRODUCTION}

- $\mathrm{n}$ general, the petroleum industry includes operations such as exploration, exploitation (production, transportation, refining and marketing of oil and crude products) and maintenance. There is a considerable dependence on global and regional oil production, coupled with the growth of the transport sector and the increase in global energy demand. As a result, global economies are continually investing in oil-based products.

In day of April 20, 2020, see Figure 1, the global petroleum industry witnessed a historic plummeting of benchmark oil below US 0 \$/barrel (oil prices plunged by $321 \%$ to $-40.32 \$$ / barrel, with oil futures trading in the negative territory, suppliers were offering to pay buyers to take oil off their hands), while Brent crude oil has fallen nearly $70 \%$ from the beginning of the year. The plummeting of the West Texas Intermediate (WTI) oil price was the direct consequence of an oversupply of fuel and a declining demand for fuel amidst travel restrictions and economic lockdowns.
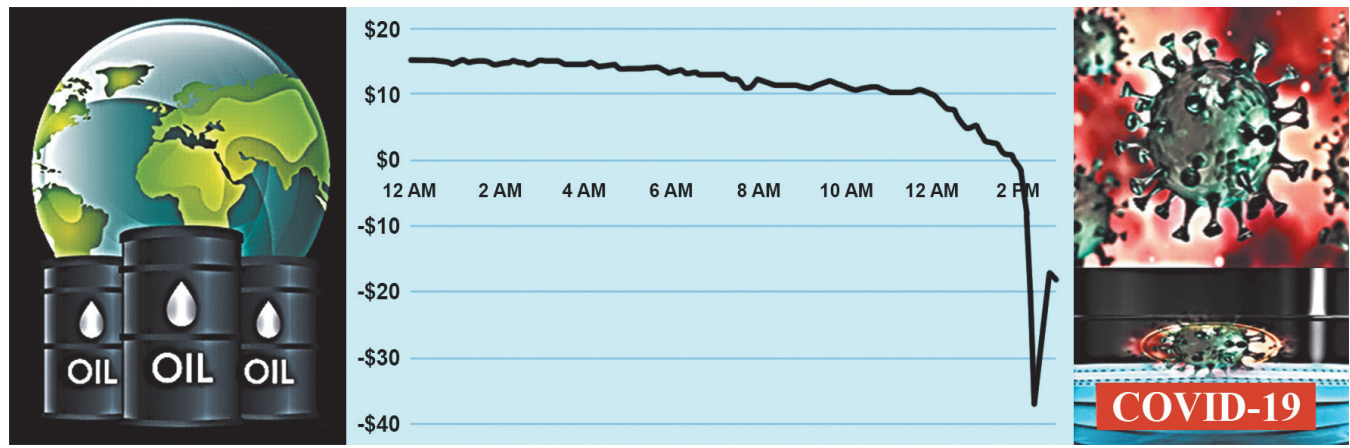

Figure 1 - Price of a barrel of oil on April 20, 2020

The Futures contracts for WTI crude in question is are basically a preorder for oil in future, but with the economy coming to a standstill, there is so much unused oil in the reserves that energy companies have no room to store it. Many companies have severely shut down to prevent the spread of the COVID-19 virus, which in turn wiped out the demand for oil as transport almost came to a halt. According to the US Energy Information Administration (EIA) report, road transport in countries under lockdowns dropped 50\% below 2019 activity, while air transport declined more than $90 \%$. As a result, the oil demand plummeted by 10.8 MMbpdyear-on-year, pushing the T1 demand in advanced economies down by $2.3 \mathrm{MMbpd}$ by 3.3 MMbpd for the rest of the world.

While the WTI fuel price relates to global oil industry, the general decline in the oil price and increasing lack of storage capacity has ripple effects on the regional oil industry and specifically in local. This is because oil producing countries depend on higher oil prices for the functioning of their economies.

While the global oil sector has already witnessed declining oil prices because of a price war between Saudi Arabia and Russia, the rise of COVID-19 will certainly exacerbate existing price declines. Amidst all this, OPEC failed to reach an effective agreement on the cut of oil production. 
All of the above factors combined have resulted in a steep decline in oil prices.

In countries where exploration is underway, oil and gas companies will weigh up their risks to establish whether to continue, delay or withdraw investment [1].

\section{IMPACT OF COVID-19 ON THE PETROLEUM INDUSTRY}

The oversupply of fuel has resulted in a lack of storage facilities because of over-capacity fuel tanks. As a result, traders are looking to store the oil in anticipation that the oil price will recover. As land-based storage is mostly full, traders are looking at very large offshore floating storage facilities and rail tanker cars, which come with practical and legal issues of their own.

The lack of storage capacity because of the demand/supply mismatch has seen traders seeking relief in the form of force majeure or hardship provisions in their contracts to avoid or delay taking delivery of more fuel. The purpose of force majeure provisions in contracts is to relax contractual obligations for a period or permanently, when an event occurs which was out of the parties' control, and which prevents performance. While it could be argued that over-capacity fuel tanks may not necessarily constitute force majeure, it could be construed as a contractual hardship. Many traders include hardship provisions in their contracts, which result in a renegotiation of terms in the event of an unforeseeable event that economically disadvantages a party to a contract and makes performance burdensome. However, the longer the situation persists, more companies may rely on force majeure or the one agreement OPEC.

\subsection{Synthesis:}

The agreement involved the 10 OPEC members (Algeria, Angola, the Republic of Congo, Equatorial Guinea, Gabon, Iraq, Kuwait, Nigeria, Saudi Arabia and the United Arab Emirates) along with the OPEC+ nations (Azerbaijan, Bahrain, Benin, Kazakhstan, Malaysia, Mexico, Oman, Russia, Sudan and South Sudan).

All but country, one except Mexico, agreed to reduce output by $23 \%$. This one country had delayed resolution of the agreement by refusing to make a larger reduction, agreeing to only cut by $6 \%$ or 100,000 bpd.

Both Russia and Saudi Arabia will reduce oil production by $2.5 \mathrm{MMbpd}$, while Iraq's $23 \%$ cut equals $1.06 \mathrm{MMbpd}$ less output.

Also, USA, Canada and the Norway have signalled they will also cut output.

But a closer look shows subtle changes that point to Saudi Arabia, Russia and their OPEC+ allies adopting a more sophisticated approach: trying to flip the shape of the oil price curve upside down. In many respects, the cartel is borrowing from the playbooks of the world's top central banks, where policy makers often focus on the interplay between long- and short-term interest rates.

The alliance, which includes 23 of the world's oil-rich nations, has traditionally targeted a reduction in inventories. But now it's also actively focusing not just on stockpiles but also on the shape of the oil curve, designing policy to influence short-term prices relative to those further in the future [2].

\section{COVID-19 AND OIL PRICES. A DUAL SHOCK}

The global petroleum industry face both the coronavirus pandemic (COVID-19) and a collapse in oil prices. Collapsing oil prices further depress demand, where oil and gas is the most important sector in many economies. Finally, potential financial market volatility could further disrupt aggregate demand. 


\section{COVID-19 И НЕФТЯНАЯ ПРОМЫШЛЕННОСТЬ}

The negative supply shock comes first from a reduction in labor - directly because workers get sick with COVID-19, the disease caused by the virus, and indirectly due to travel restrictions, quarantine efforts and workers staying home to take care of sick family members or children. Supply will also be affected by a reduction in materials, capital and intermediate inputs due to disruptions in transport and businesses of all countries.

So, mankind faces both pandemic coronavirus (COVID-19) and a fall in oil prices. The global, virus has seriously affected (see Figure 2).

$\underline{\text { Situation by WHO Region }}$ Americas: 9,841,842 Confirmed Europe: 3,451,556 Confirmed South-East Asia: 2,299,433 Confirmed Eastern Mediterranean: 1,585,458 Confirmed Africa: 834,147 Confirmed Western Pacific: 341,165 Confirmed

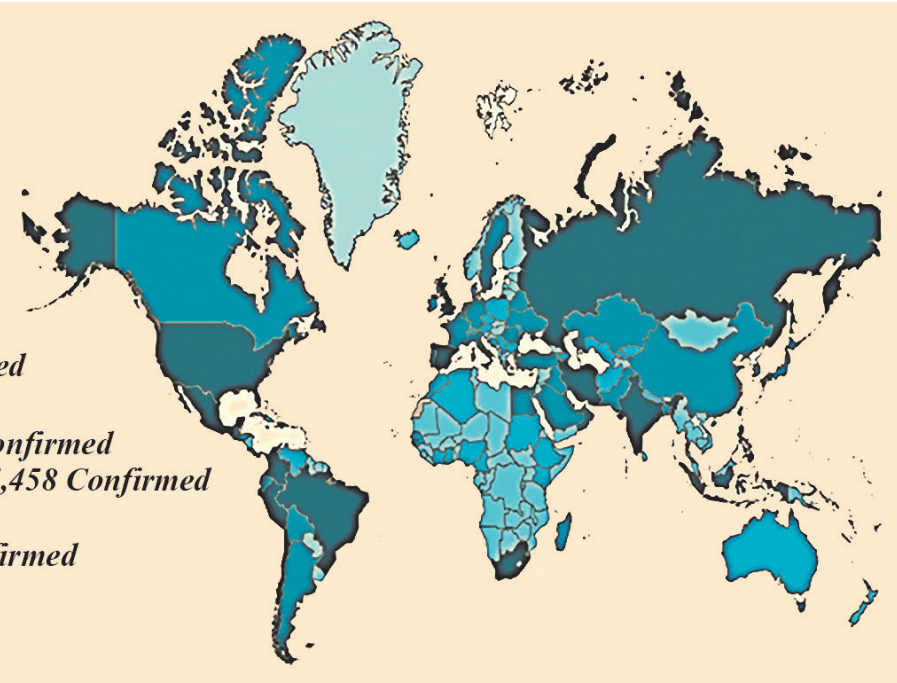

Source: World Health Organization

\section{Figure 2 - WHO Coronavirus Disease (COVID-19) Dashboard [3]} (Globally, there have been 18,354,342 confirmed cases of COVID-19, including 696,147 deaths, reported to WHO. Data last updated: 2020/8/5, 3:00pm CEST.)

Evident, the negative demand shock is both global and regional. Economic difficulties around the world and the disruption of global value chains will reduce demand for the region's goods and services, most nota. The negative supplys and demand shocks associated with COVID-19 are expected to be relatively short-lived, but dramatic, and to affect many sectors and countries. Demand and supply will recover once the pandemic subsides - and how quickly that occurs depends on the length and depth of the disruption oil and tourism.

In addition to the shock from COVID-19, the breakdown in negotiations between the Organization of the Petroleum Exporting Countries (OPEC) and its allies led to what will likely be a persistent collapse in oil prices.

The futures curve suggests that the market expects oil prices to recover slowly - not reaching $\$ 40$ per barrel until the end of 2022 (see Figure 3). 


\section{COVID-19 И НЕФТЯНАЯ ПРОМЫШЛЕННОСТЬ}

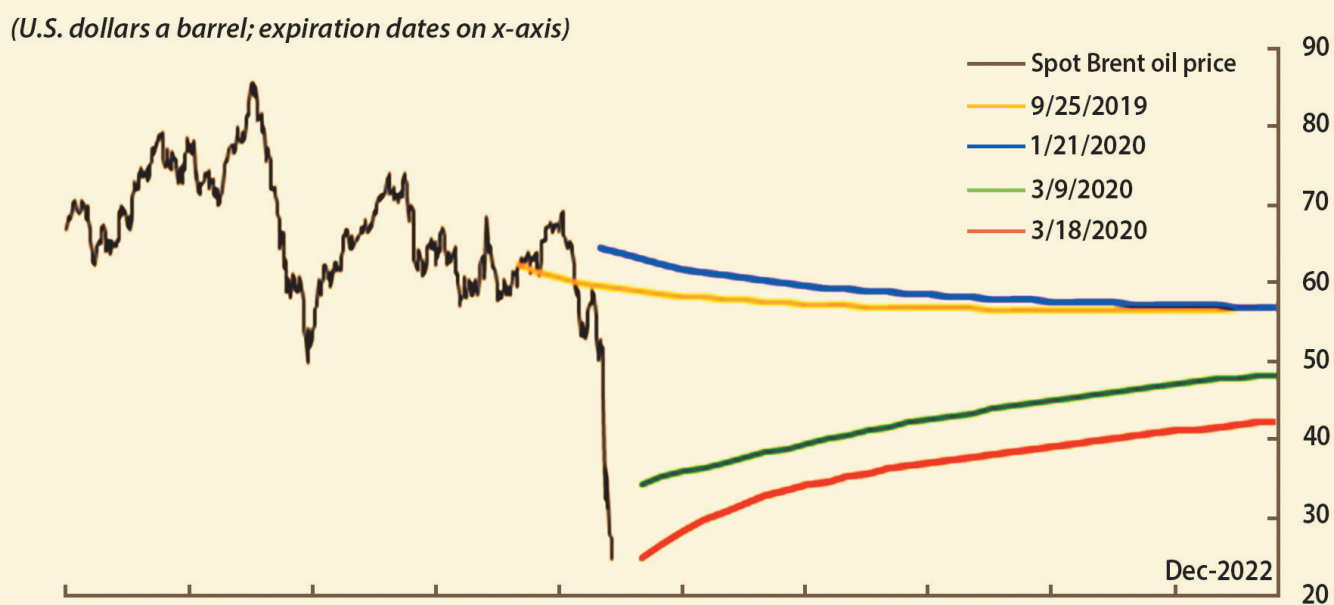

Jan-2018 Jul-2018 Jan-2019 Jul-2019 Jan-2020 Jul-2020 Jan-2021 Jul-2021 Jan-2022 Jul-2022

Source: Bloomberg, LP.

\section{Figure 3 - Spot and Forecasts of Brent Oil price [3]}

Note: The black indicates spot price of Brent crude oil. The colored lines illustrate the futures prices of Brent Crud oil on, respectively, 25 September 2019, 21 January9 March 2020, after the disintegration of the OPEC+ alliance, and 18 March 2020.

The two shocks of COVID-19 and oil price collapse are intertwined, yet distinct. On one hand, the demand component of the oil shock is linked to the sharp reduction in oil consumption stemming from precautionary measures to stop the spread of the virus, including lockdowns, which have brought economies around the world to a standstill. The estimated $10 \%$ reduction in oil consumption from 2019 , or about $10 \mathrm{mb} / \mathrm{d}$, is the result of reduced air and road travel, according to Rystad Energy, the Norwegian research company. While the depth and duration of the pandemic shock is uncertain, it is expected to be short-lived. Indeed, the severity of the shock has triggered unprecedented domestic measures in advanced and developing countries, and the imperative of global coordination to eradicate the virus will hopefully prevail. The international financial institutions are critical to the efforts of developing countries that have acute balance of payments or fiscal problems, and are now fighting COVID-19 [3].

These institutions, which can offer zero- to low-interest financing and long maturities, are best-equipped to help countries in oil industry and other developing regions deal with the dual shock. The cost of inaction, both economic and social, would be large. The payoff for action is large.

Once the spread of the virus is stopped, the preventive measures at the root of the economic recession will be rolled back. The speed of that recovery will depend on how swiftly and decisively governments take measures to mitigate the economic and financial dislocations from the health crisis. But the supply component of the oil shock is likely to be persistent and drive oil prices lower for longer. The two shocks differ in their duration but also their likely potential consequences and associated risks of inaction. 


\section{COVID-19 И НЕФТЯНАЯ ПРОМЫШЛЕННОСТЬ}

When assessing the impact of oil prices on the global economy, economists typically distinguish between supply- and demand-driven oil shocks. Demand-driven shocks are related to the evolution of global demand and as such are not expected to have an independent effect on the global economy. But the supply-driven oil shocks would normally be expected to give an independent boost to the global economy. There are several reasons why they might not - in good part because the financial propagation effects of the collapse in oil prices have caused markets for equities, bonds, and non-oil commodities to tumble.

\subsection{Policy of Prices}

Crude oil prices reflect the market's volatile and liquid nature, as well as oil being a benchmark for global economic activity.

The differences between WTI and Brent include not only price but oil type as well, with WTI producing crude oil with a different density and sulfur content (see Figure 4).

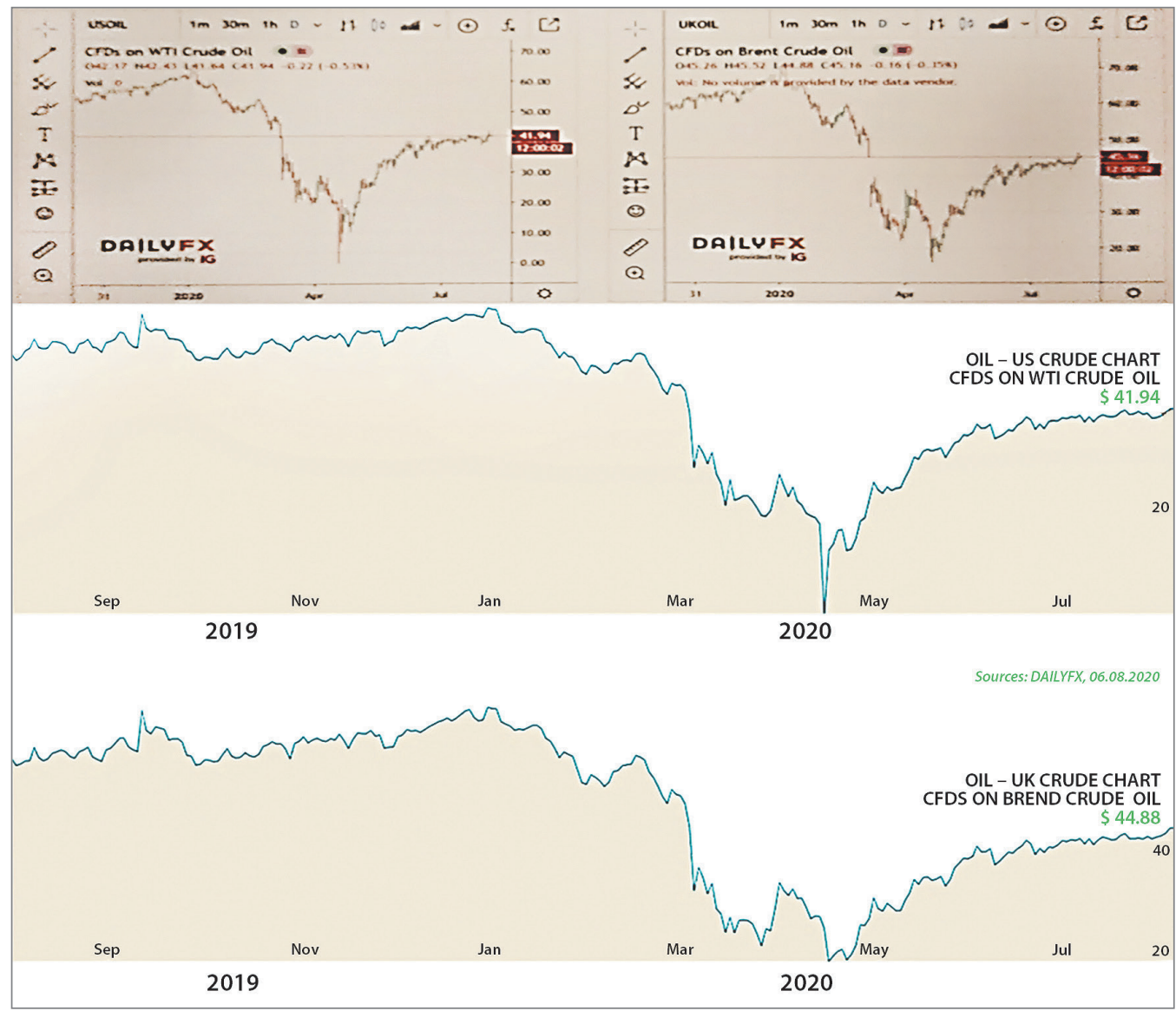

Figure 4 - WTI and Brent Crude Oil Prices chart, 06/08/2020, 12:00:02. [4]

These oil price charts provide real data and comprehensive price action on the WTI Crude and Brent Crude models. 
A simple way to get a sense of the size of the real income effect of an oil price change is to multiply the difference between production and consumption (net oil export) as a share of GDP by the percentage point change in the oil price.

While COVID-19 has caused a severe supply shock that is expected to increase unemployment and poverty, there is also a sizable feedback loop in terms of demand. Besides the loss of human lives, inaction also risks massive disruptions in supply and demand as well as illiquidity in the financial sector.

In other words, the COVID-19 shock could lead to household and corporate bankruptcies, with lasting scars on the economy and society.

In contrast, the oil price collapse is a commodity terms-of-trade shock that affects the economy through reduced export receipts and revenues in government coffers. The shock is expected to be persistent and lead to widening twin deficits:

- in a country's current balance and its government budget

- as well as increased debt if there is no fiscal consolidation.

To deal with the dual shock, authorities should sequence and tailor their responses to the severity of the shocks. They should focus first on responding to the health emergency and the associated risk of economic depression. Authorities should postpone the fiscal consolidation associated with the persistent drop in oil price and its spillovers until the recovery from the pandemic is well underway. In responding to COVID-19, authorities should boost spending on health — including producing or acquiring test kits, mobilizing and paying health workers, adding health infrastructure, and preparing for vaccination campaigns. The authorities should also use targeted cash transfers to vulnerable households and support the private sector, including small- and medium-sized enterprises in the informal sector. It is paramount to target the large number of workers in the informal sector, who have no safety net.

The battle against the spread of the novel coronavirus and its economic and social consequences will be made more difficult by empty government coffers.

In present, COVID-19 has already impacted the price and trade of crude oil. Combined effect of price-war and COVID-19 resulted crude oil price reaching low. Falling crude price has already created enough distress among the investors in onshore and offshore.

\section{IMPACT OF COVID-19 IN THE RENEWABLE ENERGY SECTOR: PRESENT AND FUTURE}

In present, the impact on the power and renewables sector is likely to be considerable, particularly as the virus spreads globally.

The renewable energy sector, which has always been one of the leading areas to promote sustainability in terms of the environment, too is not spared from being affected by the pandemic.

An amalgamation of the effects of the pandemic on the global economy and fluctuating oil prices resulting from country-wide lockdowns across the world further triggered its impact on the renewable energy industry. Not only people lost their lives to it, but also numerous industries and governments as a whole succumbed to its impacts.

Also, the for projects which are commissioned, generators may be forced to shut down or reduce capacity where their workforce is subject to quarantine measures and cannot get to site. More, risks for early stage projects or projects in the procurement phase are 


\section{COVID-19 И НЕФТЯНАЯ ПРОМЫШЛЕННОСТЬ}

particularly vulnerable to the impacts of COVID-19, which is likely to increase prices due to supply shortages, impacting profitability.

So, the breakout of the coronavirus SARS-CoV-19 (COVID-19) and its culminating transformation into a global pandemic sent shockwaves across the nations. Evident, to prevent the spread of the disease, many countries have resorted to observing countrywide lockdowns, damaging the normalcy of their economy. More, the world economy has seen new lows by trillions of dollars during this period, giving rise to times of constant anxiety about the future.

Three aspects [5] immediately come to the fore when considering the pandemics impact on Renewables:

1) The Demand;

2) Health and Safety of Society;

3) The Environment.

The environmental impact is clear to be seen with less planes in the air and less carbon-fuel vehicles on the roads. So, major cause of emission is the transportation industry, which is being revolutionised with an ongoing shift to electric vehicles and constant innovation in battery charging.

On the demand side the World Bank has stated that "Mitigation measures to slow the spread of COVID-19 have resulted in an unprecedented collapse in economic activity and transport, resulting in widespread declines in commodity prices" [5].

The COVID-19 will be a catalyst to further drive forwards renewable energy sources: wind; solar; geothermal; tidal; biomass, amongst others. The renewable market should be better defined as the sustainable market as it will encompass, previously "contentious" and new solutions.

In eventually, at level global, considering renewable energy sector or the energy industry, governments should be taking a proactive approach to discussions and carrying out an urgent review of force majeure (FM), of change in law, of material adverse change and other protections in their key contracts. Such measures will be key to maintaining an ongoing commercial relationship into the future.

\section{CONCLUSIONS}

The COVID-19 pandemic presents the world with an unprecedented policy challenge: not only will it have a severe impact on the global economy likely to exceed that of both the 2008-09 Global Financial Crisis and the Great Depression, it will take place against the backdrop of the ongoing climate crisis.

As for oil, it crude oil is one of the most in-demand commodities, with the two most popularly traded grades of oil being Brent Crude and West Texas Intermediate (WTI). Crude oil prices reflect the market's volatile and liquid nature, as well as oil being a benchmark for global economic activity.

The Brent Crude oil was originally produced from the Brent oilfield in the North Sea. About 2/3rds of all crude oil contracts around the globe include Brent Crude oil, making it the most popular marker. Its relatively low density and sulphur content are the reasons why it's described as light and sweet. One of the advantages is transportation since this type of 
oil is waterborne. The Brent Crude oil marker is also known as Brent Blend, London Brent and Brent petroleum and has a UKOIL ticker symbol.

So, two major benchmarks for pricing crude oil are the United States' WTI (West Texas Intermediate) and United Kingdom's Brent. The differences between WTI and Brent include not only price but oil type as well, with WTI producing crude oil with a different density and sulfur content. The demand for crude oil is dependent on global economic conditions as well as market speculation. Crude oil prices are commonly measured in USD. Although there have been discussions of replacing the USD with another trade currency for crude oil, no definitive actions have been taken. The oil price charts offer real dates and comprehensive price action on WTI Crude and Brent Crude patterns.

In the during pandemic of COVID-19 and beyond, policy makers must take care of oil industry as survival of oil industry holds key to revival of economies.

As for the renewable energy sector (wind; solar; geothermal; tidal; biomass, amongst others), at level globally, it must have a long-term strategy, because the industry is suffering due to problems such the risk of not being able to benefit from national government incentives, delays in the supply chain and problems in tax stock markets. More, in the future, investments in renewable energy can support economic recovery in the global.

In acknowledging the magnitude of this unprecedented challenge, the priority for governments must first be the immediate emergency response focussing on saving lives, supporting health infrastructure, food availability, and the many other urgent social and economic support measures such as short-term job allowances, direct cash handouts to citizens, or targeted liquidity support to SMEs. But solving the COVID-19 crisis cannot come at the expense of solving the longer-term issue facing humanity: the climate crisis. The real practicalities of the Pandemic have and will continue to affect the way we carry out business, whether it be oil industry or renewable energy industry.

Finally, COVID19 virus challenge is global, but the solutions have to be found both at the regional and local.

\section{REFERENCES}

1 https://www.nortonrosefulbright.com/en/knowledge/publications/9d66757b/south-africaoil-prices-drop-what-will-fuel-the-energy-industry-post-covid-19.

2 https://www.worldoil.com/news/2020/6/5/new-opecplus-deal-reveals-a-more-hands-onapproach-to-price-controls.

3 https://www.worldbank.org/en/region/mena/brief/coping-with-a-dual-shock-coronaviruscovid-19-and-oil-prices.

4 https://www.dailyfx.com/crude-oil

5 https://www.moore-global.com/insights/articles/covid-19-the-impact-on-renewable-energy

*** https://www.nortonrosefulbright.com/en/knowledge/publications/9d66757b/south-africaoil-prices-drop-what-will-fuel-the-energy-industry-post-covid-19.

*** https://smallcaps.com.au/opec-allies-agree-record-oil-production-cuts-will-it-be-enough/.

*** www.google.ro. 